\title{
Crystal and molecular structure of $\mathrm{N}$-( $p$-nitrobenzylidene)- 3-chloro-4-fluoroaniline
}

\author{
K V ARJUNA GOWDA, M K KOKILA, PUTTARAJA, M V KULKARNI* and \\ N C SHIVAPRAKASH ${ }^{\dagger}$ \\ Department of Physics, Jnanabharathi Campus, Bangalore University, Bangalore 560 056, India \\ * Department of Chemistry, Karnataka University, Dharwad 580 003, India \\ ${ }^{\dagger}$ Department of Instrumentation, Indian Institute of Science, Bangalore 560 012, India \\ MS received 7 March 2000; revised 7 July 2000
}

\begin{abstract}
The crystal structure of N-(p-nitrobenzylidene)-3-chloro-4-fluoroaniline (II) has been determined by X-ray structure analysis. This belongs to a class of benzylidene anilines. The structure was solved by direct method. The molecular packing of the non-planar molecules are held by Van der Waals and $\mathrm{F} \cdots \mathrm{H} 7, \mathrm{O} \cdots \mathrm{Cl}, \mathrm{F} \cdots \mathrm{F}$ and $\mathrm{N} \cdots \cdot \mathrm{H}$ interactions.
\end{abstract}

Keywords. Benzylidene aniline; X-ray crystallography; intermolecular interactions.

PACS Nos 61.10.i; 61.66.Hq; 61.10.Nz

\section{Introduction}

It has been known for some time that fluorine can have profound and unexpected results in biological activity. Fluorine is not a sterically demanding substituent. With its small Van der Waal's radius $(1.33 \AA)$ it closely resembles hydrogen $(1.20 \AA)$ [1]. In molecules, where conformational recognition is important minimal disturbance by a substituent is specially significant.

With the aim of pre-organizing the molecules into a packing mode in the crystalline lattice favourable for photoreactions and a few other physical properties such as non-linear optical properties super conductivity etc substitution of some chemical groups with attractive interactions between them may be of great value. In fact, in connection with photoreactions in crystals the role of fluoro substitution on molecular packing has been examined recently [2]. It has been observed that $\mathrm{C}-\mathrm{H} \cdots \cdot$. F interactions are present in many such cases. The aim of investigating the present compound (II) is two-fold.

a) Biological activity; structure activity correlation studies.

b) To find out whether $\mathrm{C}-\mathrm{H} \cdot \cdots \cdot \mathrm{F}$ interactions exists or not and to look for other possible interactions.

Benzylidene anilines (I) are a class of organic compound which is found to adopt a nonplanar arrangement in the solid state [3] and have been studied as useful models in the 
development of the principles of crystal engineering [4]. Introduction of groups like chloro, nitro and dichloro in this class of compounds revealed many interesting features like polymorphism, nature of twist of the two benzene rings and their thermal sensitivity [5]. The fluoro substituent at para-position leads to a change in the mode of packing from $\alpha$ to $\beta$ [2].

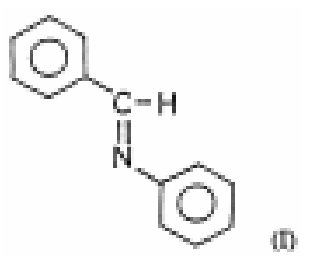

Introduction of fluoro substituent in a variety of organic compounds has been found to increase crystal densities and enhance the reactivity in solid state photochemical dimerisation [2]. On substitution of fluorine the compound becomes photoreactive in the solid state without changing the mode of packing [6]. 3-chloro-4-fluoroaniline moiety has been found to be the pharmacopnone in a variety of biologically active organofluorine compounds. In view of this, several benzylidene anilines from 3-chloro-4-fluoroanilines have been synthesized as possible anti-inflammatory agents [7].

The role of design element in solid state photochemical reactions has been recently reviewed [8]. Fluorosubstitution on coumarin was used to induce $\beta$-packing mode which underwent a stereospecific photochemical dimerisation [9].

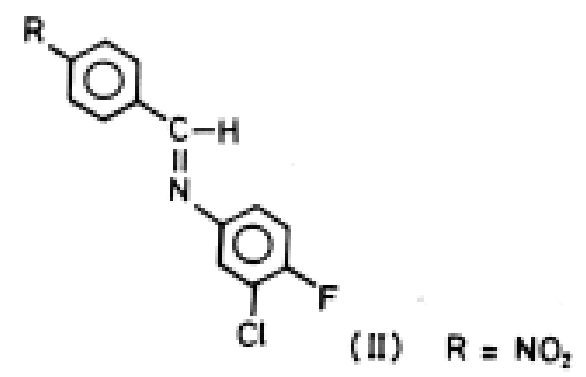

\section{Experimental}

Crystals suitable for X-ray diffraction are grown by slow evaporation technique using ethanol. X-ray intensity data are collected on Enraf-Nonius CAD-4 diffractometer with $\mathrm{Cu} K_{\alpha}$ radiation. Three dimensional intensity data were corrected for Lorentz and polarization effects. Absorption and extinction corrections are not applied. The crystallographic data and other details of experimental and refinement are summarized in table 1.

The structure was solved by direct method using NRCVAX-crystal structure solution program [10]. The structure thus obtained was refined by using a full-matrix least-squares method to a final value of $R=0.053$ on 1344 reflections. 
Table 1. Crystal data for the title compound.

\begin{tabular}{ll}
\hline Crystal morphology & Yellow needles \\
Crystal size & $0.2 \times 0.2 \times 0.2 \mathrm{~mm}$ \\
Chemical formula & $\mathrm{C} 13 \mathrm{H} 8 \mathrm{~N} 2 \mathrm{O} 2 \mathrm{C} 1 \mathrm{~F}$ \\
Molecular weight & 278.66 \\
Crystal system & Monoclinic \\
Space group & $\mathrm{P} 2{ }_{1} / \mathrm{c}$ \\
Cell constants & $a=3.816(2) \AA$ \\
& $b=12.669(2) \AA$ \\
& $c=24.677(5) \AA$ \\
Volume & $\beta=91.34(3)^{\circ}$ \\
Number of formula units $Z$ & $1192.0(7) \AA^{3}$ \\
Density (calculated) $D C$ & 4 \\
Absorption coefficient $\mu\left(\mathrm{Cu} K_{\alpha}\right)$ & $1.552 \mathrm{gm}^{\circ} / \mathrm{cm}^{3}$ \\
Unique data measured & $0.33 \mathrm{~mm}{ }^{-1}$ \\
Observed data with $I \geq 2.5 \sigma(\mathrm{I})$ & 2680 \\
$\mathrm{~F}(\mathrm{OOO})$ & 1344 \\
$\mathrm{R}$ & 278.67 \\
Rw & 0.053 \\
$\Delta \rho_{\text {min }}$ & 0.055 \\
$\Delta \rho_{\text {max }}$ & $-0.280 \mathrm{e} / \AA^{3}$ \\
\hline
\end{tabular}

\section{Results and discussion}

The fractional co-ordinates and equivalent isotropic temperature factors for non-hydrogen atoms are presented in table 2 , and the bond lengths and bond angles are presented in table 3 respectively. The general view of the molecule indicating the numbering scheme is as shown in figure 1.

The spatial arrangement of the two benzene rings indicates that the molecules have $E$-configuration, across the $\mathrm{C}=\mathrm{N}$ bond. The chloro- and fluoro-substituents attached to the aniline ring have very small deviations of $-0.031(8)$ and $-0.021(8) \AA$. The bond length $\mathrm{C} 3-\mathrm{C} 1$ in aniline ring [1.720(5) $\AA$ ] is smaller than that observed in $N-(p$ chlorobenzylidene-p-chloroaniline) [11] and the normal C-C1 bond length $1.737 \AA$ was observed in aromatic compounds [12] which may be due to the electron withdrawing $p$ fluoro substituent.

The bond lengths, associated with bridging atoms $\mathrm{C} 1, \mathrm{~N} 1, \mathrm{C} 7$ and $\mathrm{C}^{\prime}$ are of significance in reflecting the effect of substituents present in the aniline and benzylidene rings. The electron withdrawing effect of the $p$-fluoro group has resulted in the lengthening of the $\mathrm{C}=\mathrm{N}$ bond to $1.256(7) \AA$ when compared to that of the parent benzylidene ring [3] (1.237 $\AA$ ). The $\mathrm{C} 7-\mathrm{C}^{\prime}$ bond length 1.463(7) $\AA$ is greater than the bond length observed in the $p-p$ dichloro substituted compound $1.437 \AA$ [3]. The bond angle $\mathrm{C} 6-\mathrm{C} 1-\mathrm{N} 1=116.1(4)^{\circ}$ is lesser than that observed in benzylidene aniline $\left(123.7^{\circ}\right)$ [3] indicating that the electron withdrawing nitro group might have a stronger effect on the angle $\mathrm{C} 6-\mathrm{C} 1-\mathrm{N} 1$, than the 
Table 2. Positional coordinates and isotropic temperature factors Uiso $\left(\AA^{2}\right)$ for nonhydrogen atoms with e.s.d's which are in parentheses.

\begin{tabular}{lcccc}
\hline Atom & $x$ & $y$ & $z$ & Uiso \\
\hline $\mathrm{Cl}$ & $0.0866(5)$ & $0.4738(14)$ & $0.1771(6)$ & $0.0623(8)$ \\
$\mathrm{F}$ & $0.0845(10)$ & $0.2515(3)$ & $0.2065(13)$ & $0.0678(18)$ \\
$\mathrm{C} 3$ & $0.2116(13)$ & $0.4219(5)$ & $0.2386(19)$ & $0.0400(24)$ \\
$\mathrm{C} 4$ & $0.1989(14)$ & $0.3148(5)$ & $0.2475(22)$ & $0.0450(3)$ \\
$\mathrm{C} 5$ & $0.3043(16)$ & $0.2706(5)$ & $0.2953(23)$ & $0.0480(3)$ \\
$\mathrm{C} 6$ & $0.4205(14)$ & $0.3359(4)$ & $0.3366(22)$ & $0.0412(23)$ \\
$\mathrm{C} 1$ & $0.4258(12)$ & $0.4438(4)$ & $0.3298(19)$ & $0.0339(20)$ \\
$\mathrm{C} 2$ & $0.3246(14)$ & $0.4872(5)$ & $0.2799(21)$ & $0.0417(24)$ \\
$\mathrm{N} 1$ & $0.5462(11)$ & $0.5035(3)$ & $0.3746(16)$ & $0.0386(19)$ \\
$\mathrm{C} 7$ & $0.4698(13)$ & $0.5996(4)$ & $0.3786(20)$ & $0.0366(22)$ \\
$\mathrm{C} 1^{\prime}$ & $0.5872(12)$ & $0.6656(4)$ & $0.4238(19)$ & $0.0332(20)$ \\
$\mathrm{C} 2^{\prime}$ & $0.7450(12)$ & $0.6206(4)$ & $0.4696(19)$ & $0.0332(20)$ \\
$\mathrm{C} 3^{\prime}$ & $0.8517(12)$ & $0.6826(4)$ & $0.5122(19)$ & $0.0338(20)$ \\
$\mathrm{C} 4^{\prime}$ & $0.7987(12)$ & $0.7901(4)$ & $0.5087(19)$ & $0.0328(21)$ \\
$\mathrm{C} 5^{\prime}$ & $0.6430(14)$ & $0.8375(4)$ & $0.4644(21)$ & $0.0390(23)$ \\
$\mathrm{C}^{\prime}$ & $0.5369(13)$ & $0.7741(4)$ & $0.4222(21)$ & $0.0393(22)$ \\
$\mathrm{N}^{\prime}$ & $0.9152(11)$ & $0.8576(4)$ & $0.5535(17)$ & $0.0416(20)$ \\
$\mathrm{O} 1^{\prime}$ & $0.8221(12)$ & $0.9495(3)$ & $0.5542(17)$ & $0.0689(23)$ \\
O2 $^{\prime}$ & $1.0978(11)$ & $0.8190(3)$ & $0.5888(16)$ & $0.0594(21)$ \\
\hline
\end{tabular}

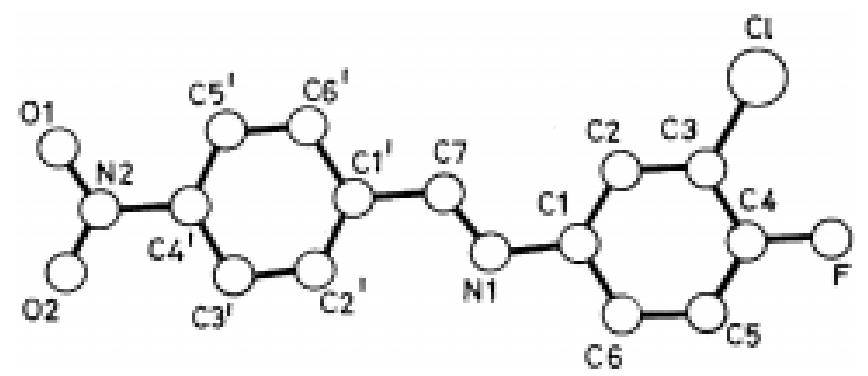

Figure 1. Perspective view of the molecule with atomic numbering scheme.

electron donating dimethylamino group. Packing diagram of the molecule viewed along $a$ axis is shown in figure 2 .

From the packing diagram it is clear that there are at least two types of intermolecular forces that stabilize the crystal structure of this molecule $[\mathrm{F} \cdots \mathrm{H}=2.22 \AA]$. The fluorine atom of one molecule is at a distance of $2.22 \AA$ from the azomethine hydrogen i.e. H7. Two such interactions are observed in a unit cell. $\mathrm{H} 7$ is further in close spatial proximity with the ortho $\mathrm{C} 2$ carbon $2.699 \AA$.

The oxygen of the nitro group also show a weak interaction with the $p$-chloro substituent, one of the oxygens being nearer $3.33 \AA$ than the other $3.40 \AA$. Similar interaction of nitro group with iodine has already been proposed as a synthon in the crystal engineering of 
Structure of aniline family

Table 3. Selected bond distances $(\AA)$ and bond angles $\left({ }^{\circ}\right)$.

\begin{tabular}{|c|c|c|c|}
\hline Atom & Bond length & Atom & Angle \\
\hline $\mathrm{Cl}-\mathrm{C} 3$ & $1.720(5)$ & $\mathrm{C} 7-\mathrm{H} 7$ & $0.960(5)$ \\
\hline $\mathrm{F}-\mathrm{C} 4$ & $1.359(6)$ & $\mathrm{C} 1^{\prime}-\mathrm{C} 2^{\prime}$ & $1.399(6)$ \\
\hline C3-C4 & $1.375(8)$ & $\mathrm{C} 1^{\prime}-\mathrm{C}^{\prime}$ & $1.389(7)$ \\
\hline $\mathrm{C} 3-\mathrm{C} 2$ & $1.379(7)$ & $\mathrm{C} 2^{\prime}-\mathrm{C} 3^{\prime}$ & $1.371(7)$ \\
\hline $\mathrm{C} 4-\mathrm{C} 5$ & $1.364(8)$ & $\mathrm{C} 2^{\prime}-\mathrm{H} 2^{\prime}$ & $1.070(4)$ \\
\hline C5-C6 & $1.383(8)$ & $\mathrm{C} 3^{\prime}-\mathrm{C} 4^{\prime}$ & $1.379(7)$ \\
\hline C5-H5 & $1.030(5)$ & $\mathrm{C} 3^{\prime}-\mathrm{H} 3^{\prime}$ & $0.960(4)$ \\
\hline C6-C1 & $1.378(7)$ & $\mathrm{C} 4^{\prime}-\mathrm{C} 5^{\prime}$ & $1.379(7)$ \\
\hline C6-H6 & $0.980(5)$ & $\mathrm{C} 4^{\prime}-\mathrm{N} 2$ & $1.465(6)$ \\
\hline $\mathrm{C} 1-\mathrm{C} 2$ & $1.401(7)$ & $\mathrm{C} 5^{\prime}-\mathrm{C} 6^{\prime}$ & $1.373(7)$ \\
\hline $\mathrm{C} 1-\mathrm{N} 1$ & $1.415(6)$ & $\mathrm{C} 5^{\prime}-\mathrm{H} 5^{\prime}$ & $0.960(4)$ \\
\hline $\mathrm{C} 2-\mathrm{H} 2$ & $0.960(4)$ & $\mathrm{C} 6^{\prime}-\mathrm{H} 6^{\prime}$ & $0.980(5)$ \\
\hline N1-C7 & $1.256(7)$ & N2-O1 & $1.217(6)$ \\
\hline $\mathrm{C} 7-\mathrm{Cl}^{\prime}$ & $1.463(7)$ & $\mathrm{N} 2-\mathrm{O} 2$ & $1.215(6)$ \\
\hline $\mathrm{C} 1-\mathrm{C} 3-\mathrm{C} 4$ & $120.5(4)$ & $\mathrm{C} 7-\mathrm{Cl}^{\prime}-\mathrm{C} 2^{\prime}$ & $120.8(4)$ \\
\hline $\mathrm{C} 1-\mathrm{C} 3-\mathrm{C} 2$ & $120.4(4)$ & $\mathrm{C} 7-\mathrm{Cl}^{\prime}-\mathrm{C} 6^{\prime}$ & $120.1(4)$ \\
\hline $\mathrm{C} 4-\mathrm{C} 3-\mathrm{C} 2$ & $119.1(5)$ & $\mathrm{C} 2^{\prime}-\mathrm{C} 1^{\prime}-\mathrm{C} 6^{\prime}$ & $119.0(4)$ \\
\hline $\mathrm{F}-\mathrm{C} 4-\mathrm{C} 3$ & $118.4(5)$ & $\mathrm{C} 1^{\prime}-\mathrm{C} 2^{\prime}-\mathrm{C} 3^{\prime}$ & $120.7(4)$ \\
\hline $\mathrm{F}-\mathrm{C} 4-\mathrm{C} 5$ & $119.6(5)$ & $\mathrm{C} 1^{\prime}-\mathrm{C} 2^{\prime}-\mathrm{H} 2^{\prime}$ & $115.6(2)$ \\
\hline C3-C4-C5 & 122.1(5) & $\mathrm{C} 3^{\prime}-\mathrm{C} 2^{\prime}-\mathrm{H} 2^{\prime}$ & $123.8(2)$ \\
\hline C4-C5-C6 & $118.9(5)$ & $\mathrm{C} 2^{\prime}-\mathrm{C} 3^{\prime}-\mathrm{C} 4^{\prime}$ & $118.4(4)$ \\
\hline C4-C5-H5 & $112.3(2)$ & $\mathrm{C} 2^{\prime}-\mathrm{C} 3^{\prime}-\mathrm{H} 3^{\prime}$ & $121.6(3)$ \\
\hline C6-C5-H5 & $128.8(2)$ & $\mathrm{C} 4^{\prime}-\mathrm{C} 3^{\prime}-\mathrm{H} 3^{\prime}$ & $119.9(3)$ \\
\hline $\mathrm{C} 5-\mathrm{C} 6-\mathrm{C} 1$ & $120.6(5)$ & $\mathrm{C} 3^{\prime}-\mathrm{C} 4^{\prime}-\mathrm{C} 5^{\prime}$ & $122.7(4)$ \\
\hline C5-C6-H6 & $120.0(3)$ & $\mathrm{C} 3^{\prime}-\mathrm{C} 4^{\prime}-\mathrm{N} 2$ & 119.1(4) \\
\hline C1-C6-H6 & $119.0(3)$ & $\mathrm{C} 5^{\prime}-\mathrm{C} 4^{\prime}-\mathrm{N} 2$ & $118.2(4)$ \\
\hline C6-C1-C2 & $119.5(5)$ & $\mathrm{C} 4^{\prime}-\mathrm{C} 5^{\prime}-\mathrm{C} 6^{\prime}$ & 118.1(5) \\
\hline C6-C1-N1 & 116.1(4) & $\mathrm{C} 4^{\prime}-\mathrm{C}^{\prime}-\mathrm{H} 5^{\prime}$ & $119.8(2)$ \\
\hline C2-C1-N1 & $124.4(5)$ & $\mathrm{C} 6^{\prime}-\mathrm{C}^{\prime}-\mathrm{H} 5^{\prime}$ & 122.1(2) \\
\hline C3-C2-C1 & $119.8(5)$ & $\mathrm{C} 1^{\prime}-\mathrm{C} 6^{\prime}-\mathrm{C} 5^{\prime}$ & 121.1(5) \\
\hline C3-C2-H2 & $115.0(3)$ & $\mathrm{C} 1^{\prime}-\mathrm{C}^{\prime}-\mathrm{H} 6^{\prime}$ & $119.0(3)$ \\
\hline $\mathrm{C} 1-\mathrm{C} 2-\mathrm{H} 2$ & $124.0(3)$ & $\mathrm{C} 5^{\prime}-\mathrm{C} 6-\mathrm{H} 6^{\prime}$ & $119.0(3)$ \\
\hline C1-N1-C7 & $120.3(4)$ & $\mathrm{C} 4^{\prime}-\mathrm{N} 2-\mathrm{O} 1$ & 118.7(4) \\
\hline $\mathrm{N} 1-\mathrm{C} 7-\mathrm{Cl}^{\prime}$ & $122.9(4)$ & $\mathrm{C} 4^{\prime}-\mathrm{N} 2-\mathrm{O} 2$ & $118.4(4)$ \\
\hline $\mathrm{N} 1-\mathrm{C} 7-\mathrm{H} 7$ & $120.0(3)$ & O1-N2-O2 & $122.8(4)$ \\
\hline $\mathrm{Cl}^{\prime}-\mathrm{C} 7-\mathrm{H} 7$ & $116.0(3)$ & & \\
\hline
\end{tabular}

4-nitro iodobenzene [9]. Though oxygen and chlorine are electronegative they differ in their electronegativities and such forces between $\mathrm{O} 1 \cdots \mathrm{C} 1$ can contribute to the stability of the crystal lattice.

Presence of weak F $\cdots . F$ interactions as stabilizing factors in the crystal structures of a variety of organic compounds has been reviewed [11]. In view of this, it is pertinent to mention an intra molecular interaction between the two ortho substituted $\mathrm{F}$ and $\mathrm{C} 1$ atoms, the distance of which is observed as $2.910 \AA$.

Another favoured $\mathrm{N}-\mathrm{H}$ interaction is between the $\mathrm{N} 1$ and the ortho hydrogen i.e. C2$\mathrm{H} 2$. However the distance between $\mathrm{N} 1-\mathrm{H} 2^{\prime} 2.886 \AA$ indicates poor interaction as they are spatially far apart. 


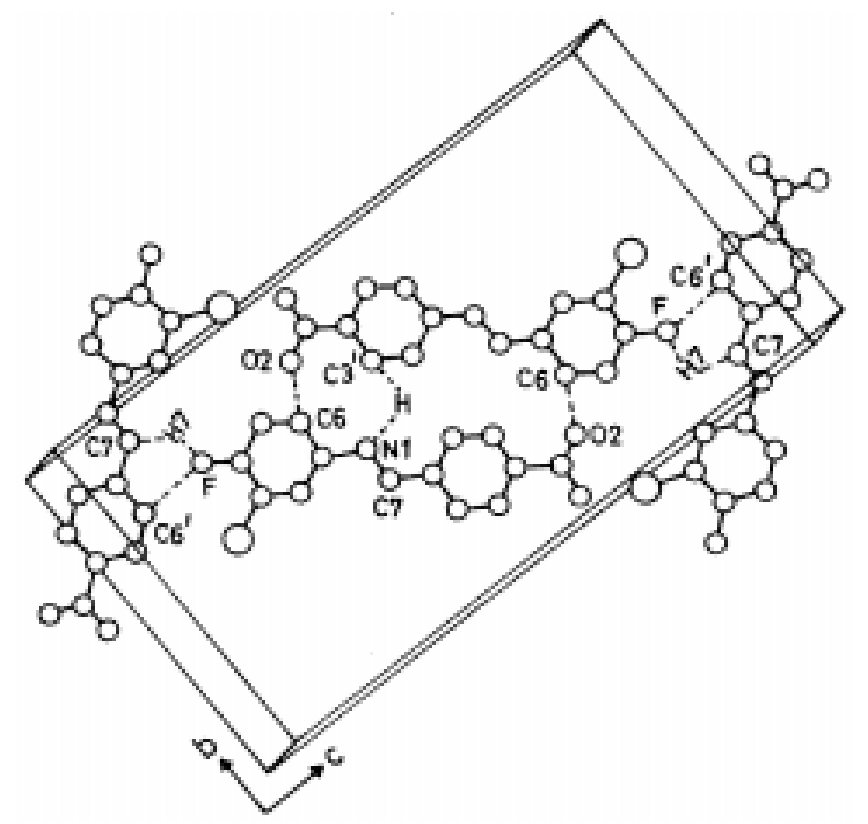

Figure 2. Packing diagram of the molecule viewed along $a$.

\section{Acknowledgements}

The authors would like to thank the referee for his valuable and constructive suggestions in improving the manuscript. One of the authors K V Arjuna Gowda gratefully thanks L V G Nargund, and his student M Srinivasmurthy, Dr. Nargund Research Foundation, Bangalore for supplying the powder form sample.

\section{References}

[1] J T Welch, Tetrahedron 16, 3125 (1987)

[2] K Vishnumurthy, T N Guru Row and K Venkatesan, J. Chem. Soc. Perkin Trans. 2, 1475 (1996)

[3] H B Burgi and J D Dunitz, J. Chem. Soc. D1, 472 (1969)

[4] Gautam R Desiraju, Angew. Chem. Int. Ed. Engl. 34, 2311 (1995)

[5] J Bernstein and I Izak, J. Chem. Soc. Perkin II 4, 429 (1976)

[6] V A Kumar and K Venkatesan, J. Chem. Soc. Perkin II 12, 2429 (1993)

[7] L V G Nargund and M Srinivasmurthy, Synthesis of fluorinated thiazolidiones and azetidinoes for pharmocological screening (Bangalore University, 1994)

[8] T N Guru Row, Co-ordination Chemistry Reviews 183, 81 (1999)

[9] V A Kumar, N S Begum and K Venkatesan, J. Chem. Soc. Perkin II 3, 463 (1993)

[10] A C Larson, F L Lee, Y Le Page, M Welisten, J P Charland, E J Gabe and P S White, NRCVAXcrystal structure system (1990)

[11] J Bernstein and G M J Schmidt, J. Chem. Soc. Perkin II 8, 951 (1972)

[12] G J Palenik, J Donohue and K N Trueblood, Acta Cryst. B24, 1139 (1968) 